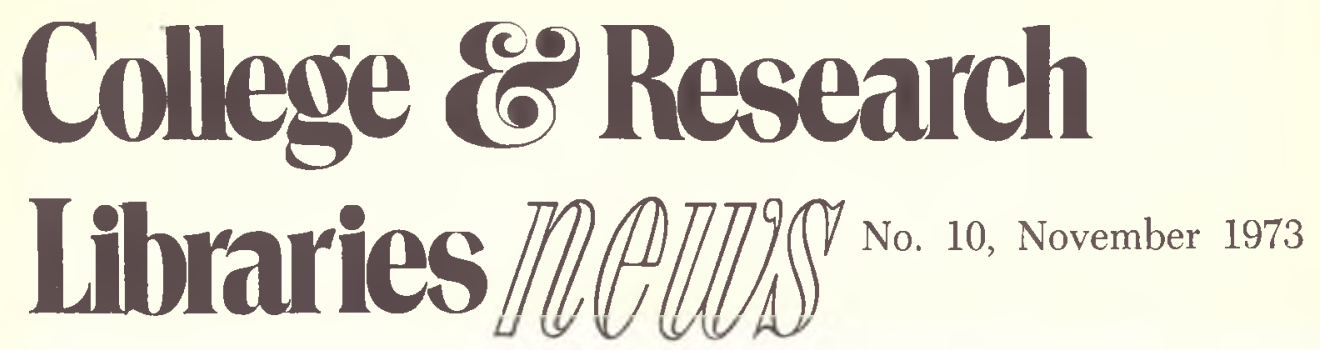

ACRL News Issue (A) of College \& Research Libraries, Vol. 34, No. 6

\title{
Draft: ALA Equal Employment \\ Opportunity Policy
}

Because of the great importance and the sensitive nature of the issue of fair and equal employment opportunity, the ALA Council Committee (Ad hoc) on Equal Employment Opportunity is presenting its draft policy statement for membership input previous to the policy finalization at the 1974 Midwinter Meeting.

The committee has sought to draft a policy which will help the Association take an aggressive stand in this matter as well as a stand which can also be effectively and speedily implemented by its members. Comments and corrections on this statement should be forwarded BEFORE December 1, 1973 to: Barbara Manchak, Assistant Head, Undergraduate Library, University of Maryland, College Park, MD 20742.

I. WHEREAS: The American Library Association, through its organized resources and membership support, is committed to a policy of equality of opportunity for all library employees, or applicants for employment, regardless of race, color, creed, sex, age, individual life style, or national origin. This policy of employment equality logically begins with recruitment to the occupation of librarianship.

Commentary: This policy is designed to update and subsume the previous $A L A$ policies on discrimination in employment, to wit, Compliance with Fair Employment Practices (1971), Non-Ethnic Minorities (1971), and Equal Opportunity for Women in Librarianship (1971) and reflect the intent of the policy on Racial Discrimination (1962), and the Advancement of Minorities in Public Library Service (1971).

II. WHEREAS: The Association not only supports the efforts of member libraries to seek full compliance with all governmental policies against discriminatory practices but also through the approval and promulgation of this policy focuses attention on the responsibility of members, both personal and institutional members, to comply with such legislation and to set institutional goals and timetables which will actively eliminate employment discrimination in libraries.

Commentary: Currently existing federal policies include:

\section{Statutes}

(a) Title VII of the Civil Rights Acts of 1964 as amended by the Equal Employment Opportunity Act of 1972.

(b) Fair Labor Standards Act of 1938 as amended, particularly by the

College \& Research Libraries is published by the Association of College and Research Libraries, a division of the American Library Associafion, 17 times yearly-6 bimonthly journal issues and II monthly, combining July. Auqust. News issues at 1201-05 Blulf St. Fulton. Mo. 65251. Subscription, $\$ 15.00$ a year or to members of the division, $\$ 5.00$, included in dues. Circulation and advertising office: American Library Association, 50 E. Huron St. Chicago, III. 606II. Second-class postage paid at Fulton, Missouri 6525I.

News editor: Allan Dyson, Moffitt Undergraduate Library, University of Calilornia, Berkeley, Calilornia 94720. Associate News editor: Susana Hinojosa. Assistant Librarian. Reference Dedartment. Molfitt Underaraduate Library. Editor: Richard $M$. Dougherty, University Library, Universify of California, Berkeley, California 94720. President, ACRL: Norman Tanis. Executive Secrepary, ACRL: Beverly Lynch, ALA. 
Equal Pay Act of 1963 and the Education Amendments of 1972 .

Executive Orders

(a) 11246 (September 24, 1965) as amended by EO 11375 (October 13, 1967) and EO 11478 (August $8,1969)$.

Federal Court Cases

(a) Griggs v. Duke Power Company 401 U.S.424, 91 S.CT. 849, 28 L.Ed. $2 d 158$ (1971).

(b) Gregory v. Litton Systems, Inc. 316 F.Supp. 401 (D.C. Cal. 1970).

Policies of the states are listed in part in American Libraries (June 1972).

\section{BE IT RESOLVED THAT:}

(1) The Council of the Association directs the Executive Director of ALA to have all Association activities, policies and programs reviewed in order to assure that fair and equal practices are followed.

(2) The Council directs the Office for Library Personnel Resources to begin immediately an aggressive program of instruction on legal equal employment requirements and the procedure for meeting such requirements and to begin an annual collection of statistical data on the employment status of women and minorities including job levels, salaries and advancement.

(3) The Association commits itself to continuing efforts for the improvement and implementation of essential legislation prohibiting discrimination.

Commentary: The ALA Committee on Legislation is created: To have full responsibility for the Association's total legislative program on all levels-Federal, State, and local. To recommend legislative policy and programs for Council approval and to take the necessary steps for implementation. To protest any legislation or executive policy adversely affecting libraries. To seek ruling and interpretations of laws and regulations affecting the welfare and development of libraries. To represent the ALA before executive and legislative branches of government as required at all levels. To provide a forum within ALA to gather information about needed legislation and to keep all units of the Association informed of the ALA legislative programs. To direct the activities of all units of the Association in matters relating to legislation.

IV. BE IT FURTHER RESOLVED THAT: To achieve the goal of equal employment opportunity for all library employees and applicants for employment, the Council of the Association:

(I) directs that ALA members noted for their expertise in equal employment efforts be appointed to a Standing Council Committee on Equal Employment Opportunity.

(2) authorizes that the Chairperson of the said Standing Committee shall serve as a voting member of the Advisory Committee to the Office for Library Personnel Resources.

(3) directs that the Equal Employment Opportunity Committee shall with the staff of the Office for Library Personnel Resources establish guidelines for the prevention of all forms of employment discrimination in libraries as prohibited by this policy; making these guidelines available to libraries, boards of library trustees, staff associations, civil service groups, library employee unions and individuals who are already employed or are seeking employment in libraries.

(4) urges the Association's investigatory body to be prepared to respond speedily and investigate thoroughly alleged employment discrimination on the basis of race, color, creed, sex, age, individual life style, or national origin from any individual or group of individuals employed in or seeking employment in libraries and to impose sanctions on libraries which are in violation of the law as well as the spirit of this policy.

Commentary: The following specific areas of concern should be covered in guidelines to promote nondiscriminatory practices: Education, Recruitment, Selection, Training, Promotion, Wages and Benefits, Procurement of Library Materials.

Program activities for the Office of Personnel Resources suggested by this policy statement include PUBLICATIONS, i.e., "EEOC Guidelines for Preventing Discriminatory Employment Practices," American Libraries (December 1972); ANNUAL STATISTICAL SURVEYS on the status of women and minorities employed in libraries; ANNUAL PUBLISHED REPORTS on recruitment and placement efforts for women and minorities; MAJOR CONFERENCE PROGRAMS fully funded which will provide leadership in focusing attention on employment equity for all library employees.

"The Staff Committee on Mediation, Ar- 
bitration and Inquiry is hereby assigned responsibility for mediation, arbitration, and inquiry, the committee is composed of senior staff members of the units of the Association with policy assignments in the areas of tenure, status, fair employment practices, due process, ethical practices, and the principles of intellectual freedom; along with one staffmember-at-large. Nothing shall preclude the committee from drawing on a temporary basis, other senior staff members when their interests are involved or they can supply needed expertise. Fact finding subcommittees shall be appointed and shall be made up of two ALA association members and one staff member. "Sanctions may be defined as the appropriate penalty or penalties incurred for violations of one or more of the ALA approved policies to which this Program of Action relates."

A. Publication of a report that includes a statement of censure, indicating the strong disapproval of ALA because of a violation of one or more of the policies to which this Program of Action relates.

B. Suspension or expulsion from membership in $A L A$.
C. Listing of parties under censure in American Libraries as a warning to persons considering employment in an institution under censure that its practices and policies are in conflict with ALA policies concerning tenure, status, fair employment practices, due process, ethical practices, and/or the principles of intellectual freedom. On the same page with such listings of censured $l i$ braries shall appear the following statement:

"The fact that the name of an institution appears on the censured list of administrations does not establish a boycott of a library, nor does it visit censure on the staff. There is no obligation for ALA members to refrain from accepting appointment in censured libraries. The ALA advises only that librarians, before accepting appointments, seek information on present conditions from the Staff Committee on Mediation, Arbitration and Inquiry at Headquarters."

(Program of Action for Mediation, Arbitration and Inquiry)

\section{Large Selection of Russian Antiquarian Material - Literary Criticism MICROFILM \\ - History \\ - Social Sciences}

Write for prices and catalog offering carefully selected lists

INTERNATIONAL MICRO-PRINT PRESERVATION, INC.

64 University Place. New York, New York 10003 